\title{
Design and Optimization of Febuxostat-loaded Nano Lipid Carriers Using Full Factorial Design
}

\section{Febukostat Yüklü Nano Lipit Taşıyıcıların Tam Faktör Tasarımı Kullanılarak Tasarımı ve Optimizasyonu}

\author{
(D) Shailendra BHATT1*, (D) Jai Bharti SHARMA¹, (D) Ruchi KAMBOJ1, (D) Manish KUMAR¹, (D) Vipin SAINI2, (D) Shailendra MANDGE3 \\ 1 Maharishi Markandeshwar College of Pharmacy, Department of Pharmaceutics, Haryana, India \\ 2Maharishi Markandeshwar University, Department of Pharmaceutics, Solan, India \\ ${ }^{3}$ Pacific University, Department of Pharmaceutics, Rajasthan, India
}

\begin{abstract}
Objectives: This work aims to develop nanostructured lipid carriers (NLCs) to improve the oral bioavailability of febuxostat (FEB).

Materials and Methods: High shear homogenization, a well-known technique, followed by bath sonication with slight modifications was used to prepare FEB-loaded NLCs using oleic acid as liquid lipid and stearic acid as solid lipid. A total of $3^{2}$ full factorial design was utilized to examine the effect of 2 independent variables, namely, X1 (liquid to solid lipid ratio) and X2 (surfactant concentration) on the Y1 (particle size) and Y2 (\% entrapment efficiency) of the drug. The prepared NLCs were evaluated for particle size, polydispersity index, zeta potential, and (\%) entrapment efficiency.

Results: The drug's highest solubility was found in the stearic (solid lipid) and oleic acid (liquid lipid), which were further chosen for NLC preparation. Result of the present study showed an increase in entrapment efficiency and a decrease in particle size with the increase in liquid lipid to solid lipid ratio. With increased surfactant concentration, a small particle size is observed. The optimized formulation's particle size and (\%) entrapment efficiency was found to be $99 \mathrm{~nm}$ and $80 \%$, respectively. The formulations' zeta potential and polydispersity index were found within the range. Compared to plain drug suspension, the optimized formulation showed higher drug release, which may be due to the presence of the higher amount of liquid lipid. The particles shown in the transmission electron microscopy were round in shape and have smooth surface. Stability studies showed that the NLC formulation can be stored for a longer time period under room condition.

Conclusion: FEB-loaded NLC were successfully prepared using full $3^{2}$ factorial design, and can be further used for oral delivery of FEB for gout treatment.
\end{abstract}

Key words: Febuxostat, nanostructured lipid carriers, oral drug delivery, oleic acid

öz

Amaç: Bu çalışmada, febukostatın (FEB) oral biyoyararlanımını iyileștirmek için nano yapılı lipit taşıyıcıların (NLC) geliştirilmesi amaçlanmıştır. Gereç ve Yöntemler: Sıvı lipit olarak oleik asit ve katı lipit olarak stearik asit kullanarak FEB yüklü NLC'leri hazırlamak amacıyla iyi bilinen bir teknik olan yüksek hızlı homojenizasyon ve ardından, modifiye edilmiş su banyosu sonikasyonu kullanıldı. X1 (sıvı/katı lipit oranı) ve X2 (yüzey aktif madde konsantrasyonu) olmak üzere iki bağımsız değișkenin Y1 (partikül boyutu) ve Y2 (\% ilaç yükleme etkinliği) üzerindeki etkisini belirlemek için $3^{2}$ faktöryel tasarım kullanılmıştır. Hazırlanan NLC'ler, partikül boyutu, polidispersite indeksi, zeta potansiyeli ve (\%) ilaç yükleme etkinliği açısından değerlendirildi.

Bulgular: Illacın çözünürlüğü, stearik (katı lipit) ve oleik asitte (sıvı lipit) kombinasyonunda en yüksek bulunduğu için NLC hazırlanmasında bunlar kullanıldı. Bu çalışma ile, sıvı lipit/katı lipit oranının artmasıyla ilaç yükleme etkinliğinin artıı̆ı, partikül boyutunun ise azaldığı gösterilmiştir. Artan yüzey aktif madde konsantrasyonu ile de partikül boyutunun azaldığı gözlemlendi. Optimize edilmiş formülasyonun partikül boyutu ve (\%) ilaç yükleme etkinliği sırasıyla 99 nm ve \%80 olarak bulundu. Formülasyonların zeta potansiyeli ve polidispersite indeksi, aralık içinde bulundu. İlaç süspansiyonu ile karşılaștırıldığında, optimize edilmiş formülasyonunun daha yüksek ilaç salımı gösterdiği, bunun da daha yüksek miktarda sıvı lipitin varlığından kaynaklanıyor olabileceği sonucuna varıldı. Transmisyon elektron mikroskobunda parçacıkların sferik şekilde ve pürüzsüz bir yüzeye sahip oldukları tespit edildi. Stabilite çalışmaları, NLC formülasyonunun oda koşullarında daha uzun süre saklanabileceğini göstermiştir. Sonuç: FEB yüklü NLC, $3^{2}$ faktöryel tasarım kullanılarak başarıyla hazırlanmıştır. Gut tedavisi için FEB'nin oral yolla verilmesi için FBE yüklü NLC'ler kullanılabilir.

Anahtar kelimeler: Febuksostat, nanoyapılı lipit tașıyıcılar, oral ilaç uygulama, oleik asit

*Correspondence: shailu.bhatt@gmail.com, Phone: +8107663903 ORCID-ID: orcid.org/0000-0001-9405-3311

Received: 16.07.2019, Accepted: 12.12.2019

Turk J Pharm Sci, Published by Galenos Publishing House. 


\section{INTRODUCTION}

The most convenient route for drug administration is the oral route because it offers multiple dosage forms selectivity and high patient compliance.' Not just the drug's solubility but also its other inherent characteristics, like physiological milieu in the gastrointestinal tract including $\mathrm{pH}$ value and bile salts, slows down the drug's absolute absorption. ${ }^{2,3}$

In mid-90's, Professor R. H. Müller (Germany) and Professor M. Gasco (Italy) started to research on the capability of lipid-based drug delivery system, that is, solid lipid nanoparticles. ${ }^{4}$ However, drug loading is a significant disadvantage of such dosage form. The incorporation of a liquid lipid in the nanoparticle preparation helps incorporate more drugs in the nanoparticle and enhance the nanocarrier's physical stability. This liquid lipid-containing nanoparticles were further named nanostructured lipid carriers (NLCs) ${ }^{5,6}$ These are made up of biocompatible solid and liquid lipids. ${ }^{7}$ NLCs are better than other colloidal carriers because of their drug loading capacity; and thus, have been investigated to more extent in pharmaceutical modernization. ${ }^{8}$ NLCs are also helpful in other administration routes of administration, such as dermal, oral, ocular, and pulmonary. In topical transporter, NLC also shows high drug release, drug targeting, and proper lipophilic and hydrophilic drug molecules absorption. ${ }^{9.10}$

One of the most common crystal-induced arthropathies is gout, which is caused by arthritis infiammation. Other gout problems that may arise are metabolic syndrome, renal disease, and cardiovascular disease." Hyperuricemia is an abnormality that is mostly found in children and adolescents. Because of its low concentration in the serum, even pediatricians cannot measure children's uric acid level. According to a recent study, hyperuricemia occurs because of obesity and noncommunicable diseases like cardiovascular disorders. More attention has been given to it in children and adolescents.12,13

Another powerful, non-purine particular xanthine oxidase inhibitor is febuxostat (FEB). It is used to treat hyperuricemia in grown-ups with gout. ${ }^{14} \mathrm{FEB}$ is a biopharmaceutics classification system class 2 drug and is acidic in nature (pKa 3.08). ${ }^{15}$ According to the Food and Drug Administration, FEB tablets show low oral bioavailability of $49.9 \%$ because of its low water solubility and low enzymatic degradation. ${ }^{16}$ This research aims to develop the FEB-loaded NLC formulation using high shear homogenization technique followed by bath sonication method.

\section{MATERIALS AND METHODS}

FEB was received as a gift sample from Arbindo pharmaceuticals in Dehradun, India. Oleic acid, methanol AR, and sodium hydroxide pellets were purchased from Qualikems fine chemicals in Mumbai, India. Disodium hydrogen phosphate and potassium dihydrogen phosphate were purchased from S. D. Fine Chemicals, Ltd in Mumbai, India. Stearic acid and Tween 80 were purchased from Central Drug House Ltd. Vardaan House Daryaganj in New Delhi, India. All ingredients were of analytical grade.

\section{Methods}

\section{Selection of lipids}

Solid and liquid lipid was selected based on the drug's extreme solubility in various lipids. ${ }^{17}$ The solid lipid was selected based on the solubility studies of the drug in stearic acid, glyceryl monostearate, cetyl alcohol, palmitic acid, whereas liquid lipid was examined in castor oil, isopropyl myristate, and oleic acid. In glass vials, the solid lipid was accurately weighed and heated to $70^{\circ} \mathrm{C}$. FEB of $10 \mathrm{mg}$ was added to these vials with continuous stirring. It was cooled to room temperature and was microscopically examined for precipitation. Solid lipids that did not show any precipitation were selected for further studies..$^{18}$

\section{Formulation of FEB-loaded NLC}

\section{Design of the experiment}

To study the effect of 2 independent variables $X_{1}$ (liquid to solid lipid concentration) and $X_{2}$ (surfactant concentration) on the drug's particle size $\left(Y_{1}\right)$ and entrapment efficiency $\left[(E E) ; Y_{2}\right.$ ), a full $3^{2}$ factorial design was used. Table 1 represents the $3^{2}$ factorial design along with factors and levels.

\section{Statistical analysis}

DESIGN-EXPERT ${ }^{\oplus}$ version 13.0 was used to perform the statistical analysis.

\section{Preparation of FEB-loaded NLC}

The NLC was prepared by high shear homogenization followed by bath sonication with slight modifications. ${ }^{8}$ The lipid phase was melted in a water bath at $85^{\circ} \mathrm{C}$, and then the drug was added. The lipid and aqueous phases were prepared separately. The surfactant solution or aqueous phase was prepared by adding Tween 80 in water. To form a suspension, a preheated surfactant solution was added to the melted lipid. It was further homogenized for $15 \mathrm{~min}$ at $12,000 \mathrm{rpm}$ by the high shear homogenizer (Remi Motors Ltd, Mumbai, India). All the formulations were subjected to a 5-min bath sonication (Hwashin Technology, Seoul, Korea) for uniform size distribution..$^{19}$ In a cooling centrifuge, the dispersion was centrifuged at $10,000 \mathrm{rpm}$ for $60 \mathrm{~min}$ at $10^{\circ} \mathrm{C}$, thereafter. To get the desired particle size, the sedimented soft pellet was separated from supernatant and resuspended in $20 \mathrm{~mL}$ of distilled water, which contained $2 \%-3 \%$ Tween 80 as stabilizer, with stirring for 10 minutes and again subjected to ultrasonication for $1 \mathrm{~min}$.

\section{Evaluation of FEB-loaded NLC}

\section{Particle size}

After proper dilution with distilled water, the particle size and zeta potential were measured. The scattering angle was fixed at $173^{\circ} \mathrm{C}$, and the temperature was maintained at $25^{\circ} \mathrm{C}$.

\section{Entrapment efficiency}

The formulation was centrifuged at $10,000 \mathrm{rpm}$, and the supernatant was collected and was used to calculate the EE. Then, dilution was made up to $10 \mathrm{~mL}$ with phosphate-buffered

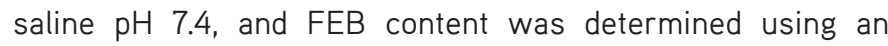
ultraviolet spectrophotometer at $315 \mathrm{~nm}$. 
Table 1. Experimental design for Febuxostat-loaded nanostructured lipid carriers

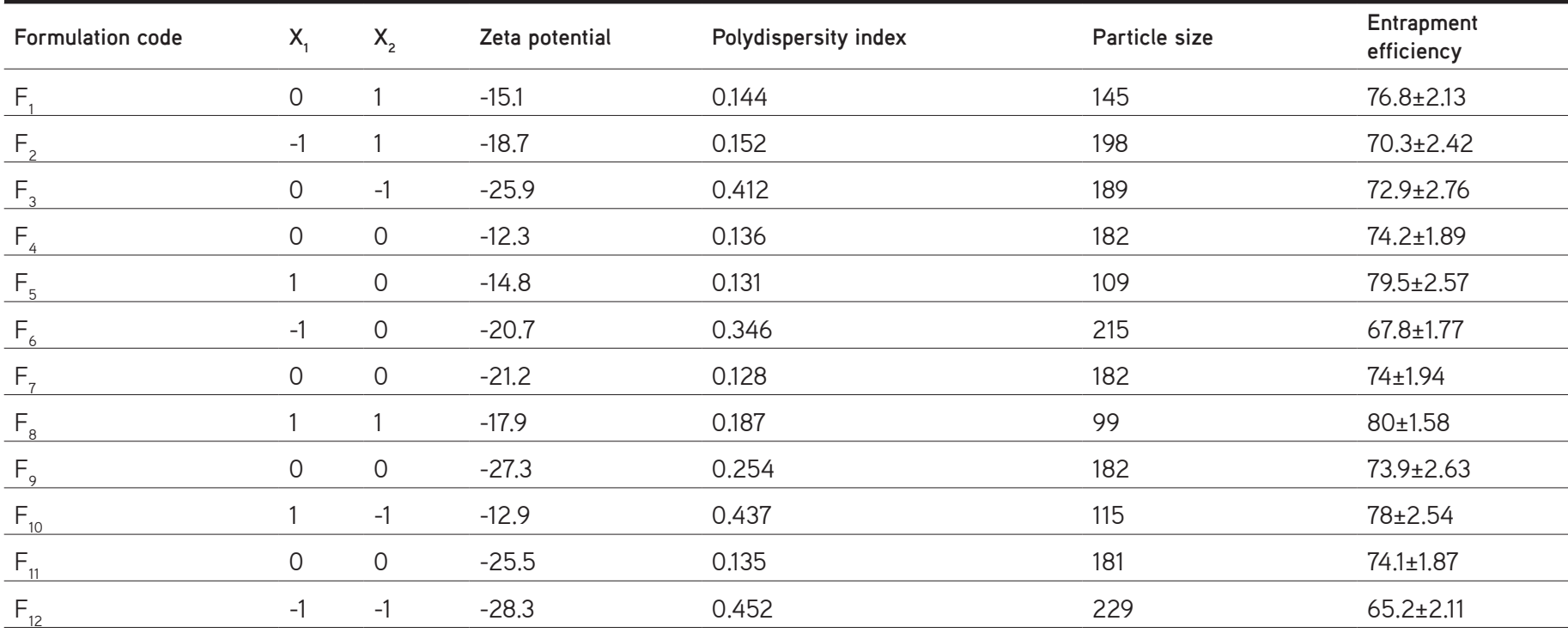

$X_{1}$ : Liquid lipid to solid lipid ratio $(-1=1: 9,0=5: 5,+1=9: 1), X_{2}$ : Concentration of surfactant $(-1=3 \%, 0=4 \%,+1=5 \%)$

The drug's EE was calculated as follows: ${ }^{8}$

(\%) EE: Total amount of drug - drug in supernatant x100

Total amount of drug

\section{Optimization of formulation}

The design master was used for optimization. Highest (\%) EE and minimum particle size was the basis in selecting the optimized formulation.

\section{Interaction between the factors}

To statistically evaluate all the results, One-Way analysis of variance was used. $P$ value gives the different independent variables' impact on dependent responses such as EE and particle size. Further, the reduced model was generated by omitting non-significant terms ( $p>0.05$ ) from the full polynomial model. The reduced polynomial model was used to evaluate the effect of independent variables on the responses.

\section{In vitro drug release studies}

The plain drug suspension and prepared NLC's in vitro drug release study was carried out using the dialysis sac method, based on a previously published method with slight modifications. ${ }^{19}$ An accurately measured amount of plain drug solution and prepared NLC equivalent to $5 \mathrm{mg}$ of FEB were introduced into the sac; and the sac was properly tied with a thread at both ends. The sac was then hanged in $200 \mathrm{~mL}$ of phosphate buffer $\mathrm{pH} 7.4$, with $1 \%$ polysorbate 80 and kept on a magnetic stirrer. The receptor compartment temperature was maintained at $37^{\circ} \mathrm{C} \pm 1^{\circ} \mathrm{C}$ at a predetermined time, and, with the help of a pipette, aliquots of $5 \mathrm{~mL}$ were withdrawn and replaced with fresh buffer at each time. The sample was filtered using a membrane filter $(0.45 \mu \mathrm{m})$ and was analyzed spectrophotometrically at $315 \mathrm{~nm}$. For blank solutions, the same procedure was repeated.
Characterization of optimized FEB-loaded NLC

Surface morphology study

To study the surface morphology of optimized formulations, transmission electron microscopy [(TEM); Philips Tecnai-20, USA] with an accelerating voltage of $120.0 \mathrm{kv}$ was used. The NLC dispersion was prepared in distilled water, and a drop of dispersion was placed on the carbon-coated copper grid followed by drying.

\section{Stability study}

Freeze-dried optimized formulation was used to carry out stability studies, according the International Conference on Harmonisation regulations. The samples were stored in vials for $3 \mathrm{mo}$ and kept at atmospheric conditions of $25 \pm 2^{\circ} \mathrm{C} / 60 \pm 5 \%$ relative humidity $(\mathrm{RH})$ and $40 \pm 2^{\circ} \mathrm{C} / 75 \pm 5 \% \mathrm{RH}$ in a stability chamber (Macro Scientific Work Pvt Ltd., New Delhi, India) in order to check their stability. Also, at specified intervals, such as $0,15,30,60$, and $90 \mathrm{~d}$, these samples' physical appearance and EE were determined.

\section{RESULTS AND DISCUSSION}

\section{Solid and liquid lipid selection}

Compared with other lipids, the solid and liquid lipid drug solubility was found highest in stearic and oleic acid, respectively. The were selected for NLC preparation as they did not show precipitation in the solubility studies of FEB.

\section{Evaluation of optimized NLC}

Zeta potential and polydispersity index

Colloidal dispersion stability is evaluated by zeta potential. It measures the repulsion degree between similarly charged particles to prevent the particle aggregation. Polydispersity ranges from 0 to 1 , and its index is the width measurement of the particle size distribution. An index near 0 has narrow-size distribution. As shown in Table 1, the mean polydispersity index 
value and zeta potential of drug-loaded NLC formulations $F_{1}$ to $F_{12}$ varied in the range of 0.135 to 0.452 and -12.3 to $-28.3 \mathrm{mv}$, respectively. In Figure 1, the optimized formulation $F_{8}$ showed zeta potential of $-17.9 \mathrm{mv}$. It was found in previous studies that only the electrostatic repulsion is not responsible for the stability of nanoparticles but to formulate stable nanoparticles, steric stabilizer also has a significant effect. The surfactant's high concentration compensates missing electrostatic repulsion and stabilizes the dispersion for a long duration. ${ }^{20}$ The steric stability fto NLC is provided by Tween 80 's high concentration.

\section{Optimization of formulation}

\section{Entrapment efficiency}

As shown in Table 1, all the NLC formulations' EE was remarkably increased from $65.2 \pm 1.25$ to $80 \pm 2.27 \%$. EE was found to be $80 \%$ for optimized formulation. Results on the incorporation of liquid to solid lipids shows that more drug is entrapped in the NLC. ${ }^{21}$ regression analysis was used to obtain the polynomial equation of the full model for EE. The full model is as follows:

$Y_{1}: 74.23+5.70 X_{1}+1.83 X_{2}-0.9375 X_{1}^{2}+0.2625 X_{2}^{2}-0.7750 X_{1} X_{2}$

The non-significant terms from the full model were removed ( $p>0.05)$ to obtain a reduced model as follows:

$Y_{2}: 74.23+5.70 X_{1}+1.83 X_{2}-0.9375 X_{1}{ }^{2}+0.2625 X_{2}{ }^{2}$

The higher positive coefficient in the equation indicates the raising variable increasing the response and effect of factor on the response. $X_{1}, X_{2}, X_{1} X_{2}$, and $X_{1}^{2}$ factors were found to be significant based on their $p$ values. The calculated $f$ value for the given model was found very low compared with the tabular $f$ value ( $\alpha: 0.05,2$, respectively), which clearly demonstrates that the omitted terms does not significantly affect the prediction of EE. It was found in this study that EE increases significantly by increasing the surfactant concentration and liquid to solid lipid ratio. The high drug solubility in the melted lipids and more space provided for drug accommodation resulted in high EE.

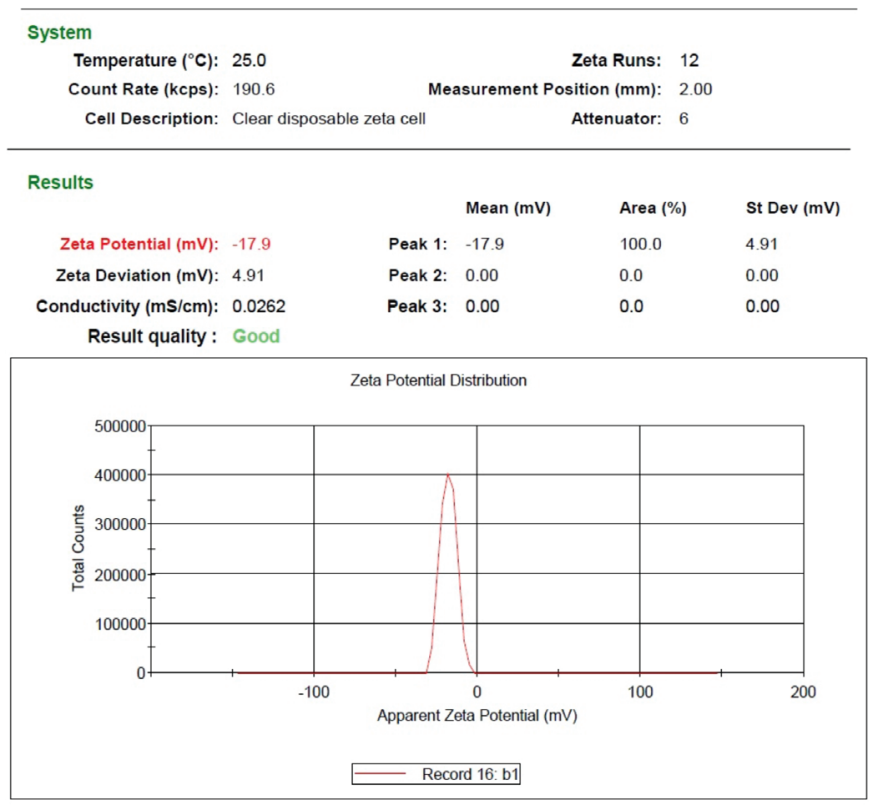

Figure 1. Zeta potential of optimized formulation
High liquid lipid proportion helps increase drug solubility in the lipid matrix, hence, high \% EE was observed. The 3D surface response plot for \% EE is shown in Figure 2.

\section{Particle size}

To confirm the produced particles' nano-range, particle size measurement was required and are presented as z-average diameter. All the formulations' particle size ranges from 99-229 nm, as shown in Table 1. Formulation $F_{8}$ showed considerably smaller mean particle size of $99 \mathrm{~nm}$. It was confirmed from the data obtained from the experimental design that the model is significant. The polynomial equation of the full model for the particle size was obtained by regression analysis. The full model is as follows:

$Y_{2}:$ 179.58-53.17X $X_{1}-15.17 X_{2}-13.25 X_{1}{ }^{2}-8.25 X_{2}{ }^{2}+3.75 X_{1} X_{2}$

Non-significant terms from the full model were removed ( $p>0.05$ ) to obtain a reduced model as follows:

$Y_{2}: 179.58-53.17 X_{1}-15.17 X_{2}-13.25 X_{1}^{2}-8.25 X_{2}^{2}$

Based on the $p$ value, $X_{1}, X_{2}, X_{1}^{2}$ and $X_{2}^{2}$ factors were found to be significant. The calculated $f$ value for the given model was found very low compared with the tabular $f$ value $(\alpha: 0.05$, 2 , respectively), which clearly demonstrates that the omitted terms does not significantly affect particle size prediction. From the above study, it was found that particle size decreases when the liquid to solid lipid ratio increases. ${ }^{22,23}$ The surfactant concentration $\left(X_{2}\right)$ is also a critical factor that significantly affects the particle size. An increase in NLC formulation's surfactant concentration reduces the interfacial tension between the lipid and dispersion; thus, NLC with smaller particle size are formed. The optimized formulation's particle size was found to be $99 \mathrm{~nm}$. Figure 3 shows the 3D surface response plot for particle size.

\section{Characterization of optimized FEB-loaded NLC}

\section{Surface morphology study}

From TEM study, it was found that NLC particles are spherical in shape and have a smooth surface, which is illustarated in Figure 4. The NLC's shape is in correlation with the previous findings. TEM study also proved that the NLC's particle size is

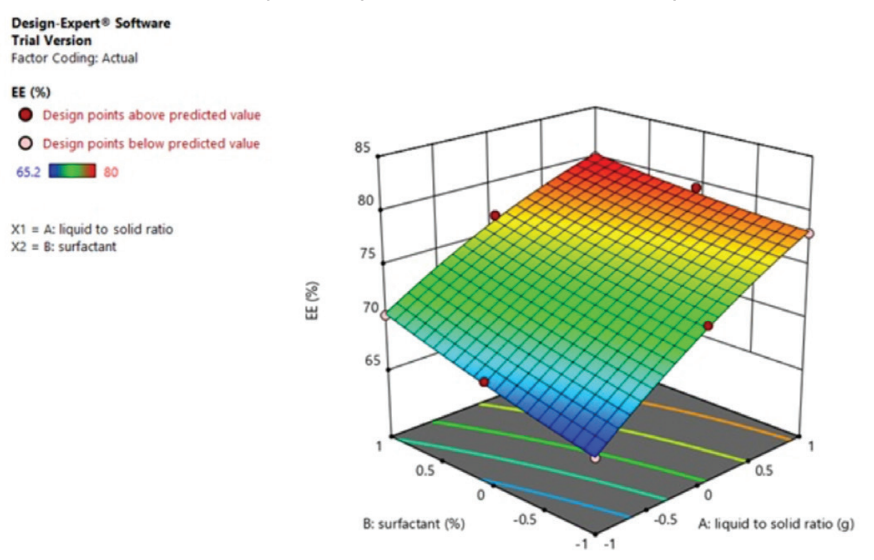

Figure 2. 3D surface response plot for entrapment efficiency EE: Entrapment efficiency 
less than $100 \mathrm{~nm}$, which is reliably equal to the particle sizes calculated by zetasizer.

\section{In vitro drug release}

Figure 5 shows the percent cumulative drug release that was studied over a period of $12 \mathrm{~h}$. In the second hour, NLC demonstrated a high burst release. Optimized formulation $\left(\mathrm{F}_{8}\right)$ showed enhancement in drug release compared to a plain drug suspension, and this is because of the presence of a higher liquid lipid amount. More liquid lipid stays at the outer shell of nanoparticles and shown essentially greater solubility for hydrophobic drugs which gives burst release in drug profile. As shown in Figure 6, the drug release was then fitted into the zero order, first order, and Higuchi kinetic model. NLC's drug release characteristics were best fitted to the Higuchi model. The correlation was determined for kinetics models. As shown in Table 2, the value of $\mathrm{R}^{2}$ indicates that the drug release characteristics were best fitted to Higuchi kinetic model.

\section{Stability study}

This table provides data for the optimized formulation stability of $\left(F_{8}\right)$. At the given stability conditions, no change in physical appearance was observed. It was also observed in accelerated conditions that there is a slight decrease in EE. The results show that storage of lipid-based formulation is not suitable under the accelerated temperature because the drug starts degrading under this condition or temperature. Table 3 shows the data for the stability study. Thus, with the help of this table, it can be concluded that the formulated NLC can be stored for

\section{Design-Experte Software \\ Factor Coding: Actual \\ partical size $(\mathrm{nm})$ \\ - Design points above predicted value \\ O Design points below predicted value \\ $99 \square 229$ \\ $\mathrm{X}_{1}=\mathrm{A}$ : liquid to solid ratio \\ $x_{2}=8$ : surfactant}

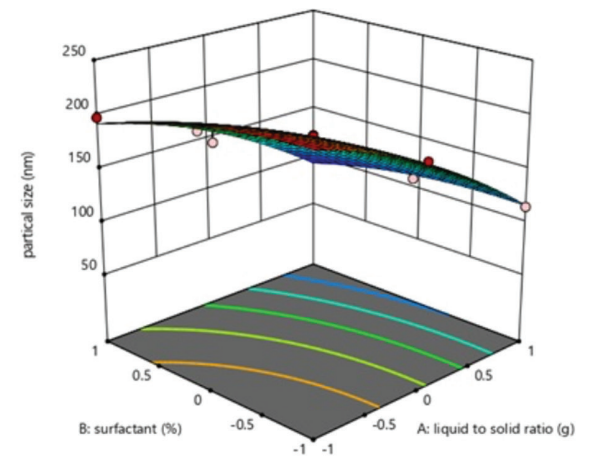

Figure 3. 3D surface response plot for particle size

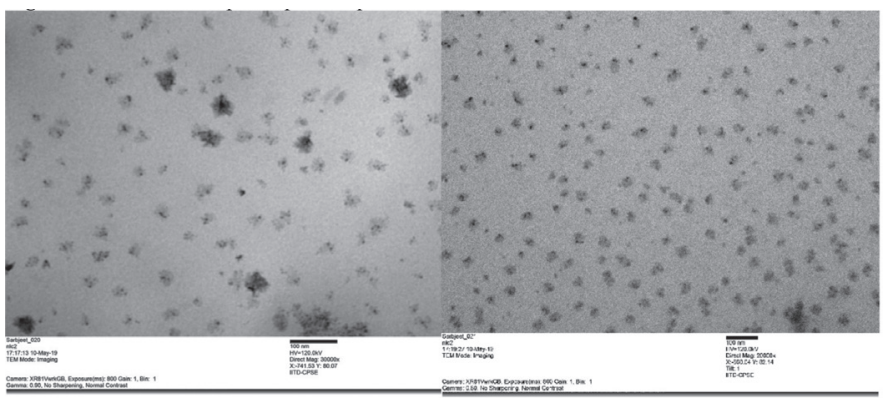

Figure 4. Transmission electron microscopy (TEM) image of optimized formulation longer period of time under room condition rather than in the accelerated condition.

\section{CONCLUSION}

With the use of high shear homogenization followed by bath sonication technique, NLC was successfully prepared and optimized. To study the effect of liquid to solid lipid ratio and surfactant concentration on the drug's particle size and EE, a full $3^{2}$ factorial design was utilized. Based on the solubility studies, stearic and oleic acid were selected as the solid and liquid lipid, respectively, and tween 80 was used as the surfactant. From the above study, it was found that particle size and (\%) EE are significantly affected by both liquid to solid lipid

\section{Table 2. Slope and $R^{2}$ values of drug release kinetics by various} models

\begin{tabular}{llll} 
Slope no. & Model & Slope & $\mathrm{R}^{2}$ \\
\hline 1 & Zero order & 6.570 & 0.973 \\
\hline 2 & First order & -0.069 & 0.95 \\
\hline 3 & Higuchi equation & 0.038 & 0.978 \\
\hline 4 & Korsemeyer Peppas equation & 1.089 & 0.638 \\
\hline
\end{tabular}

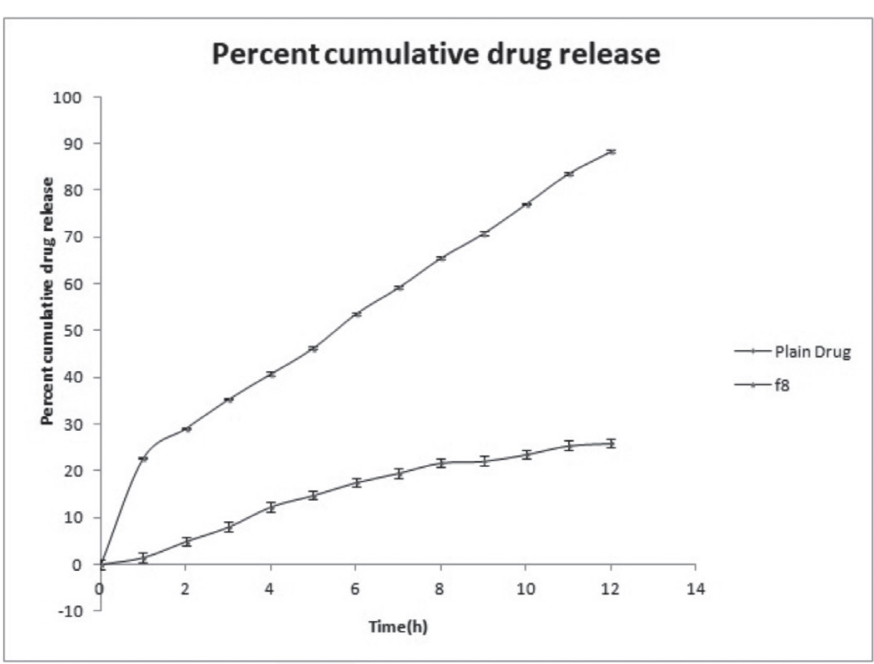

Figure 5. Comparison of in vitro release profile of optimized formulation and plain drug suspension

\section{Higuchi model release kinetics}

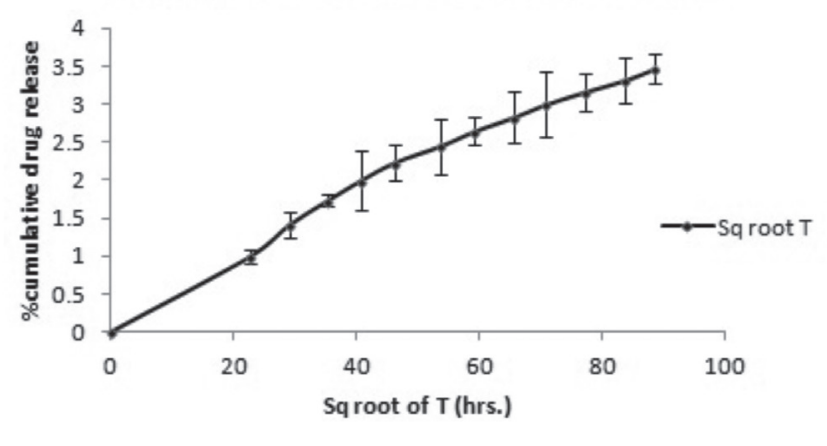

Figure 6. Drug release kinetics by Higuchi model 
Table 3. Stability study data for optimized formulation $\left(\mathrm{F}_{8}\right)$

\begin{tabular}{|c|c|c|c|c|c|}
\hline & & $25^{\circ} \mathrm{C} \pm 2^{\circ} \mathrm{C} / 60 \% \pm 5 \% \mathrm{RH}$ & & $40^{\circ} \mathrm{C} \pm 2^{\circ} \mathrm{C} / 75 \% \pm 5 \% \mathrm{RH}$ & \\
\hline Slope no. & Time (days) & Physical appearance & Entrapment efficiency \pm SD (\%) & $\begin{array}{l}\text { Physical } \\
\text { appearance }\end{array}$ & $\begin{array}{l}\text { Entrapment efficiency } \pm \\
\text { SD (\%) }\end{array}$ \\
\hline 1 & 0 & \multirow{5}{*}{$\begin{array}{l}\text { White colored suspension } \\
\text { throughout the study }\end{array}$} & $80 \pm 2.79$ & \multirow{5}{*}{$\begin{array}{l}\text { White suspension } \\
\text { throughout the study }\end{array}$} & $80 \pm 2.79$ \\
\hline 2 & 15 & & $79.87 \pm 2.68$ & & $79.97 \pm 2.63$ \\
\hline 3 & 30 & & $79.80 \pm 2.57$ & & $78.52 \pm 2.52$ \\
\hline 4 & 60 & & $79.74 \pm 3.52$ & & $77.44 \pm 1.15$ \\
\hline 5 & 90 & & $78.85 \pm 2.32$ & & $75.93 \pm 2.12$ \\
\hline
\end{tabular}

$\mathrm{RH}$ : Relative humidity, SD: Standard deviation

ratio and surfactant concentration significantly. By increasing the surfactant concentration and liquid to solid lipid ratio, EE was found to be increased. High \% EE resulted from high liquid lipid proportion, which helps increase drug solubility in the lipid matrix. The interfacial tension between the lipids are reduced with the increase in surfactant; and a decrease in particle size is resulted from dispersion. All formulations' zeta potential and polydispersity index were within range. The high concentration of tween 80 compensates missing electrostatic repulsion and provides steric stability to NLC. TEM images show the spherical globules nanosized particles with a smooth surface area; and NLC's particle size is obtained less than $100 \mathrm{~nm}$, which is in good agreement with the zetasizer results. In vitro drug release study showed the sustained release of drug up to $12 \mathrm{~h}$. Stability study showed that the formulation possesses good stability at room temperature, whereas the accelerated temperature is not an appropriate storage condition for lipid-based formulation. FEB-loaded NLCs were successfully prepared and can be used for oral delivery of FEB in gout treatment.

Conflicts of interest: No conflict of interest was declared by the authors. The authors alone are responsible for the content and writing of the paper.

\section{REFERENCES}

1. Soni K, Rizwanullah M, Kohli K. Development and optimization of sulforaphane-loaded nanostructured lipid carriers by the Box Behnken design for improved oral effcacy against cancer: in vitro, ex vivo and in vivo assessments. Artif Cells Nanomed Biotechnol. 2018;46(Sup1):1531.

2. Porter CJ, Trevaskis NL, Charman WN. Lipids and lipid-based formulations: optimizing the oral delivery of lipophilic drugs. Nat Rev Drug Discov. 2007;6:231-248.

3. Liu C, Kou Y, Z Xin Z, Cheng H, Chen X, Mao S. Strategies and Industrial Perspectives to Improve Oral Absorption of Biological Macromolecules. Expert Opin Drug Deliv. 2018;15:223-233.

4. Müller RH, Mäde K, Gohla S. Solid lipid nanoparticles (SLN) for controlled drug delivery - a review of the state of the art. Eur J Pharm Biopharm. 2000;50:161-177.

5. Müller RH, Shegokar R, Keck CM. 20 years of lipid nanoparticles (SLN and NLC): present state of development and industrial applications. Curr Drug Discov Technol. 2011;8:207-227.
6. Müller RH, Radtke M, Wissing SA. Nanostructured lipid matrices for improved microencapsulation of drugs. Int J Pharm. 2002;242:121-128.

7. Muchow M, Maincent P, Muller RH. Lipid nanoparticles with a solid matrix (SLN, NLC, LDC) for oral drug delivery. Drug Dev Ind Pharm. 2008;34:1394-1405.

8. Gadad AP, Tigadi SG, Dandagi PM, Mastiholimath SV, Bolmal BU. Rosuvastatin Loaded Nanostructured Lipid Carrier: For Enhancement of Oral Bioavailability. Indian J Pharm Edu Res. 2016;50:605-611.

9. Luan J, Zheng F, Yang X, Yu A, Zhai G. Nanostructured Lipid carriers for Oral delivery Of baicalin: In Vitro and in Vivo evaluation. Colloids Surf A Physicochem Eng Asp. 2015;466:154-159.

10. Motawea A, Gawad AE, Borg T, Motawea M, Tarshoby M. The Impact of Topical Phenytoin Loaded Nanostructured Lipid Carriers in Diabetic Foot Ulceration. Foot (Edinb). 2019;40:14-21.

11. Kuo CF, Grainge MJ, Zhang W, Doherty M. Global epidemiology of gout: prevalence, incidence and risk factors. Nat Rev Rheumatol. 2015;11:649662.

12. Wilcox WD. Abnormal serum uric acid levels in children. J Pediatr. 1996;128:731-741.

13. Yamanaka H. Gout and hyperuricemia in young people. Curr Opin Rheumatol. 2011;23:156-160.

14. Maddileti D, Jayabun SK, Nangia A. Soluble Cocrystals of the Xanthine Oxidase Inhibitor Febuxostat. Cryst Growth Des. 2013;13:3188-3196.

15. Ernst ME, Fravel MA. Febuxostat: a selective xanthine-oxidase/xanthinedehydrogenase inhibitor for the management of hyperuricemia in adults with gout. Clin Ther. 2009;31:2503-2518.

16. Khosravan R, Grabowski B, Wu JT, Joseph-Ridge N, Vernillet L. Effect of food or antacid on pharmacokinetics and pharmacodynamics of febuxostat in healthy subjects. Br J Clin Pharmacol. 2008;65:355-363.

17. Shete H, Patravale V. Long chain lipid based tamoxifen NLC. Part I: Preformulation studies, formulation development and physicochemical characterization. Int J Pharm 2013;454:573-583.

18. Lakhani P, Patil A, Taskar P, Ashour E, Majumdar S. Curcuminloaded Nanostructured Lipid Carriers for ocular drug delivery: Design optimization and characterization. J Drug Deliv Sci Technol. 2018;18:30184-30189.

19. Shah NV, Seth AK, Balaraman R, Aundhia CJ, Maheshwari RA, Parmar GR. Nanostructured lipid carriers for oral bioavailability enhancement of raloxifene: Design and in vivo study. J Adv Res. 2016;7:423-434.

20. Thatipamula R, Palem C, Gannu R, Mudragada S, Yamsani M. Formulation and in vitro characterization of domperidone loaded solid 
lipid nanoparticles and nanostructured lipid carriers. Daru. 2011;19:2332.

21. Abbas H, Refai H, Sayed NE. Superparamagnetic iron oxide-loaded lipid nanocarriers incorporated in thermosensitive in situ gel for magnetic brain targeting of clonazepam. J Pharm Sci. 2018;107:2119-2127.

22. Fathi HA, Allam A, Elsabahy M, Fetih G, El-Badry M. Nanostructured lipid carriers for improved oral delivery and prolonged antihyperlipidemic effect of simvastatin. Colloids Surf B Biointerfaces. 2018;162:236-245.
23. Khan AA, Mudassir J, Akhtar S, Murugaiyah V, Darwis Y. Freeze-Dried Lopinavir-Loaded Nanostructured Lipid Carriers for Enhanced Cellular Uptake and Bioavailability: Statistical Optimization, in Vitro and in Vivo Evaluations. Pharmaceutics. 2019;11:97. 